\title{
Announcements Annonces
}

\section{From Boiardo to Tasso}

The Center for Renaissance Studies at the Newberry Library announces a conference entitled "Ferrara: Cultural Change from Boiardo to Tasso." The conference is to be held April 27-29, 1995 in Chicago. For more information, please write to the Newberry Library Center for Renaissance Studies, 60 West Walton Street, Chicago, Illinois 60610-3380, USA.

\section{Mikhail Bakhtine}

Colloque sur Mikhaïl Bakhtine et la pensée dialogique du 3-10 août 1995 à Cerisy-laSalle, France. Prière de communiquer avec le responsable du colloque, le Prof. Clive Thompson, Department of French, University of Western Ontario, London, Ontario N6A 3K7.

\section{Reinventing the Middle Ages and Renaissance}

This conference, organized by the Arizona Center for Medieval and Renaissance Studies, will focus on the issue of periodization, i.e. how the medieval and Renaissance times defined themselves and were later defined. Dates: 16-18 February, 1995. Please contact: Prof. Robert E. Bjork, Arizona Center for Medieval and Renaissance Studies, Arizona State University, Box 872301, Tempe, Arizona 85287-2301, USA.

\section{Antiquity Revisited}

"Antiquity Revisited" is the subject of the Fourth Annual Interdisciplinary Symposium in Medieval, Renaissance and Baroque Studies, 17-18 February, 1995, at the University of Miami. Please write to: Prof. James E. Connolly, Department of Foreign Languages, University of Miami, Coral Gables, Florida 33124, USA.

\section{Les Essais de Montaigne et Marie de Gournay}

Colloque sur les rapports entre Michel de Montaigne et Marie de Gournay: du 31 mars 
au $1^{\mathrm{er}}$ avril 1995 à l'Université Duke. Prière d'écrire au Prof. Marcel Tetel, Department of Romance Studies, Box 90237, Duke University, Durham, North Carolina 277080257, USA.

\section{El sujeto colonial femenino}

Le sujet colonial féminin: culture et histoire en Amérique latine du XVI ${ }^{e}$ au XVIII siècle. Cette conférence aura lieu du 10-14 avril 1995 à l'Université du Tennessee. Pour de plus amples renseignements: Prof. Oscar Rivera-Rodas, Department of Romance Languages, University of Tennessee, Knoxville, Tennessee 37996-0460, USA.

\section{Société Canadienne d'Études de la Renaissance}

Le congrès annuel de la Société Canadienne d'Études de la Renaissance aura lieu les

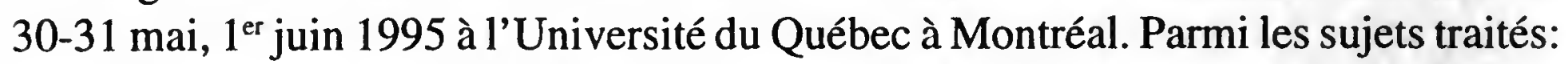
la représentation des $\mathrm{XV}^{e}$ et $\mathrm{XVI}^{\mathrm{e}}$ siècles aux $\mathrm{XIX}^{e}$ et $\mathrm{XX}^{\mathrm{e}}$ siècles, la frontière Moyen Âge/Renaissance, les femmes et l'humanisme, l'essai à la Renaissance, les femmes et l'humanisme, et le XVI ${ }^{e}$ siècle et la Nouvelle-France. Pour proposer des communications, veuillezécrire au Prof. Brenda Dunn-Lardeau, Département d'Études littéraires, Université du Québec à Montréal, Case postale 8888, Succ. A, Montréal, Québec H3C $3 \mathrm{P} 8$.

\section{Canadian Society for Renaissance Studies}

The annual meeting of the Canadian Society for Renaissance Studies will be held May 30 and 31, June 1, at the University of Quebec at Montreal. Among the topics selected are: Fifteenth and Sixteenth century representations in the Nineteenth and Twentieth centuries; the border between the Middle Ages and the Renaissance; Women and Humanism; Renaissance Essayists; and the Sixteenth century in New France. To submit proposals, please write to Prof. Brenda Dunn-Lardeau, Département d'Études littéraires, Université du Québec à Montréal, Case postale 8888, Succursale A, Montréal, Québec H3C 3P8. 